\title{
Living-donor fresh parathyroid tissue allotransplantation as treatment for permanent hypoparathyroidism: case report
}

\section{Alotransplante de tecido paratireoideano fresco de doador vivo como tratamento do hipoparatireoidismo permanente: relato de caso}

\author{
Daniel Duarte Gadelha ${ }^{1}$. Wellington Alves Filho ${ }^{1}$. Marjorie Azevedo Jales Brandão ${ }^{1}$. Claudia Maria Costa \\ de Oliveira ${ }^{1}$. Catarina Brasil d'Alva ${ }^{1}$. Virgínia Oliveira Fernandes ${ }^{1}$. Renan Magalhaes Montenegro Junior ${ }^{1}$. \\ 1 Universidade Federal do Ceará (UFC), Unidade de Pesquisa Clínica (CH-UFC/EBSERH), Fortaleza, Ceará, Brasil.
}

\begin{abstract}
Introduction: the standard hypoparathyroidism treatment consists of replacing calcium and active vitamin D (calcitriol), but it does not correct the underlying abnormality, parathyroid hormone (PTH) deficiency. Both the disease and its treatment are responsible for many morbidities that affect multiple organs and systems. Therefore, parathyroid allotransplantation has been described as an alternative treatment option, especially in refractory cases. Objectives: to verify if parathyroid allotransplantation is effective as a treatment for permanent hypoparathyroidism. Methodology: fresh parathyroid tissue was obtained from a 36-yearold male with a past medical history of hyperparathyroidism secondary to end-stage renal disease and immediately implanted in the recipient's non-dominant forearm, a 57-year-old female with refractory hypoparathyroidism, despite high doses of calcium and calcitriol replacement. Corticosteroid immunosuppression was performed for 10 days. Results: the allograft showed no evidence of functionality eleven months after transplant. The procedure was considered safe. Conclusion: more studies are required to validate this technique and improve its results.
\end{abstract}

Keywords: Allograft. Hypoparathyroidism. Tissue transplant. Parathyroid.

\section{RESUMO}

Introdução: o tratamento padrão do hipoparatireoidismo consiste na reposição de cálcio e vitamina $\mathrm{D}$ ativa (calcitriol), mas não corrige a anormalidade de base: a deficiência de paratormônio (PTH). Tanto a doença quanto o seu tratamento são responsáveis por diversas morbidades que afetam múltiplos órgãos e sistemas. O alotransplante de paratireóide tem sido descrito como uma alternativa de tratamento, especialmente em casos refratários. Objetivo: verificar se o alotransplante de paratireoide é efetivo como tratamento do hipoparatireoidismo permamente. Metodologia: tecido paratireoideano fresco foi obtido de um doador de 36 anos do sexo masculino, portador de hiperparatireoidismo secundário a insuficiência renal crônica terminal e imediatamente implantado no antebraço não dominante da receptora, uma mulher de 57 anos com controle inadequado da doença, apesar de reposição de altas doses de cálcio e de calcitriol. Imunossupressão com corticosteroides foi realizada por 10 dias. Resultado: o aloenxerto não mostrou evidência de funcionalidade onze meses após o transplante. O procedimento foi considerado bastante seguro. Conclusão: mais estudos são necessários para validar esta técnica e melhorar seus resultados.

Palavras-chave: Aloenxerto. Hipoparatireoidismo. Transplantes de tecidos. Paratireoide.

Corresponding author: Daniel Duarte Gadelha, Rua Eliseu Oriá, 1653, José de Alencar, Fortaleza, Ceará. CEP: 60.830-035. Telefone: +55 85 99692-1252. E-mail: ddgadelha@yahoo.com.br

Conflict of interests: The authors have no conflicts of interest to declare.

Received: 28 Out 2021; Revised: 03 Nov 2021; Accepted: 08 Nov 2021. 


\section{BACKGROUND}

Hypoparathyroidism is a disease characterized by PTH deficiency or absent production, leading to hypocalcemia and hyperphosphatemia. About $75 \%$ of cases occur after anterior cervical surgery. Autoimmune involvement of parathyroid glands is the second most common etiology. When the duration of hypoparathyroidism is greater than six months, it is called permanent. ${ }^{1}$

The disease is related to morbidities directly related to hypocalcemia and/or hyperphosphatemia or indirectly associated with its treatment, either by insufficient or excessive replacement of calcium and/or calcitriol. Multiple systems can be affected: renal (nephrolithiasis, nephrocalcinosis, chronic kidney disease), central nervous system (convulsions, calcifications), neuropsychiatric (anxiety, depression, reduced quality of life), peripheral nervous system (tetany, paresthesias, muscle cramp), respiratory (laryngospasm), cardiovascular (arrhythmias) and ophthalmological (cataracts). ${ }^{1-3}$

The standard treatment consists of replacing calcium and active vitamin D (calcitriol), but it does not correct the underlying abnormality: PTH deficiency. Therefore, new therapies based on the PTH molecule (recombinant human PTH - rhPTH) have been described in recent years, with good results, but it has a high cost and is not available on a large scale. ${ }^{4-8}$ In addition, long-term studies are needed to ensure their safety. Both PTH (1-34) and PTH (1-84) carry a black-box warning of a risk of osteosarcoma. ${ }^{8}$

Parathyroid allotransplantation has been reported with good results for the treatment of permanent hypoparathyroidism. Although it is still considered an emerging and alternative therapy, it is cited as more physiological. At the same time, it corrects the PTH production deficiency and as a real possibility of cure through the drastic reduction or even suspension of calcium and calcitriol replacement. ${ }^{9-22}$ In addition, it is a procedure with considerably lower costs than $\mathrm{rhPTH},{ }^{19}$ which can be interesting in countries with difficulty in financing more expensive therapies.

This article reports the first parathyroid allotransplantation performed in Brazil. We describe a case of livingdonor parathyroid allotransplantation as a treatment for a 57-year-old woman with permanent post-surgical hypoparathyroidism.

\section{CASE PRESENTATION}

A 57-year-old female underwent total thyroidectomy in March 2019 due to papillary thyroid carcinoma. During the postoperative period, she presented prominent symptoms of hypocalcemia: adynamia, muscle spasms, continuous paresthesias in the hands and feet. Permanent hypoparathyroidism was confirmed, requiring high doses of calcium and calcitriol (3.6g/day of elemental calcium and $1.75 \mu \mathrm{g} /$ day of calcitriol) for symptom relief and treatment of hypocalcemia. Hospital admission was necessary on three occasions for intravenous calcium administration.
She also reported a significant reduction in quality of life due to the intensity of the symptoms and the excessive number of pills she was taking. After the procedure has had approved by the Hospital Ethics Committee, the patient was invited to undergo parathyroid allotransplantation as an alternative to the standard treatment of hypoparathyroidism.

The donor was a 36-year-old male who needed to undergo parathyroidectomy due to hyperparathyroidism secondary to end-stage chronic kidney disease. He was ABO compatible (donor $\mathrm{O}+$ and recipient $\mathrm{A}+$ ).

Both the recipient and the donor were screened for possible infectious diseases that could contraindicate the procedure: hepatitis B (HbsAg, total anti-Hbc), hepatitis C (anti-HVC), syphilis (VDRL), Chagas disease, human immunodeficiency virus (anti-HIV 1 and 2), cytomegalovirus (anti-CMV IgG and anti-CMV IgM) and toxoplasmosis (IgG and IgM). Additional screening for Human T-cell Lymphotropic Virus (anti-HTLV 1 and 2) was performed on the donor. Allotransplantation was performed on December 2, 2020.

\section{SURGICAL PROCEDURE}

The parathyroid was removed from the donor through an incision in the anterior cervical region. After careful dissection, isolation of one parathyroid and separation of fatty tissue, fibrotic capsule, and blood vessels was performed. A frozen section histologically confirmed non-neoplastic parathyroid tissue. Then, fresh parathyroid was divided into 45 small particles and immediately washed with isotonic saline solution, followed by its implantation under the fascia of the recipient's left forearm brachioradialis muscle (non-dominant arm) through a small incision of approximately three centimeters $(3 \mathrm{~cm})$. Figure 1 shows the steps for the parathyroid gland removal and its preparation for implantation in the recipient.

\section{IMMUNOSUPPRESSION}

The immunosuppression protocol chosen was adapted from studies by Yucesan et al., ${ }^{11.13}$ consisting of methylprednisolone $250 \mathrm{mg}$ intravenous administration one hour before graft implantation, followed by a $125 \mathrm{mg}$ dose on the second day and $60 \mathrm{mg}$ on the third day. After that, oral prednisone $5 \mathrm{mg}$ /day for seven days, completing ten days of immunosuppression.

Antiparasitic treatment was administered with Albendazole $400 \mathrm{mg} /$ day for five days and Secnidazole $1 \mathrm{~g}$ in a single dose before the procedure due to high doses of corticosteroids.

\section{FOLLOW-UP}

The study follow-up protocol consists of a collection of laboratory tests by peripheral puncture of the forearm vein on the first day after graft implantation and one and two weeks after, followed by new measures in one, two, three, six, nine, and twelve months after the procedure: PTH (ipsilateral and contralateral to determine its gradient), total calcium, 
albumin, phosphorus, and magnesium as well as 24-hour urinary calcium collection at the exact time.

The procedure occurred without complications, and the patient was discharged after one hour. She did not experience significant pain, bleeding, or infectious complications. However, five months after graft implantation, there was still no evidence of its functionality. PTH levels remained undetectable, and the patient persisted with the same need for calcium and calcitriol replacement.

Figure 1. Living-donor parathyroid gland allotransplantation. A. Donor: surgical identification and removal of parathyroid glands. B. Isolation of parathyroid glands after washing and removing surrounding tissues. C. Fragmentation of parathyroid tissue. D. Recipient: incision in the forearm and allograft implant. E. Completion of the procedure.

A

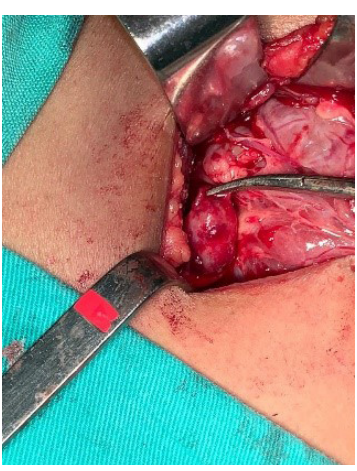

D

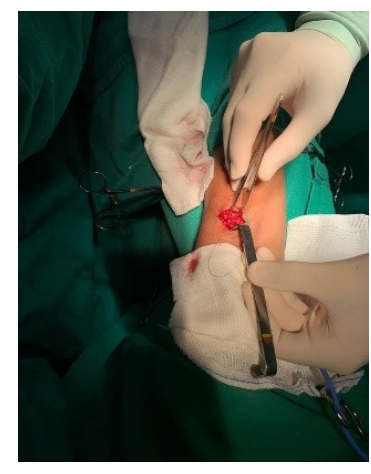

B

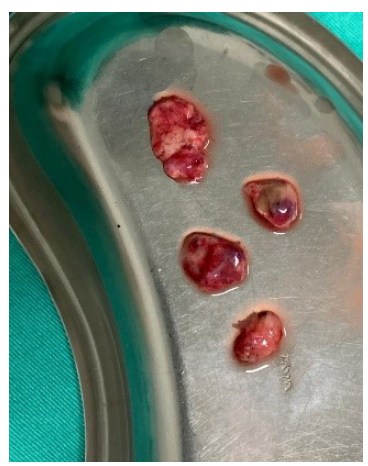

$\mathbf{E}$

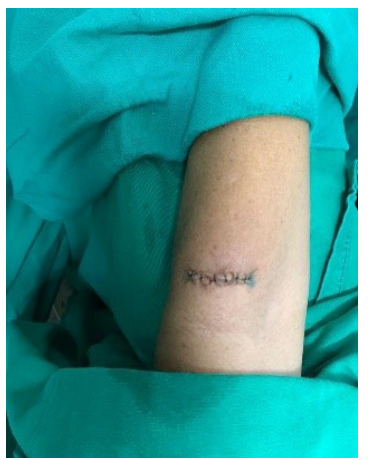

C

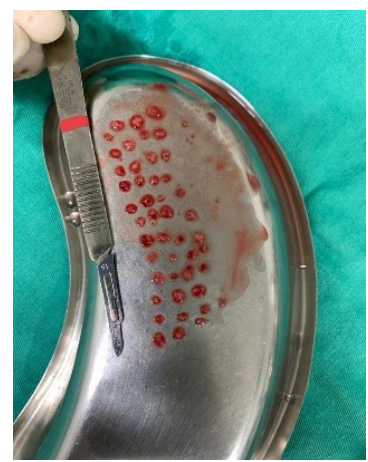

\section{DISCUSSION}

Parathyroid allotransplantation has been reported using different methodologies. Avoiding immune graft rejection is a crucial objective to be achieved, and the strategies described vary significantly. $\mathrm{ABO}$ and Human Leucocyte Antigens (HLA) compatibility are among them. ${ }^{11,13,15,16,19}$ Risks related to immunosuppression, such as susceptibility to infections and cancer, can be mitigated through techniques that hinder the immune recognition of the graft. They consist of encapsulated, cultured, and cryopreserved parathyroid tissue. Some studies that used them report good results without the need for immunosuppression., ${ }^{9,14,22,23}$ However, they are costly procedures and require well-trained staff.

On the other hand, advances in the management of immunosuppression in solid organ transplants (for example, in kidney and liver transplants) have enabled good safety with fewer adverse effects. ${ }^{24}$ Some studies on parathyroid allotransplantation report the safety of immunosuppression, whether used in the short ${ }^{11-13,18,21}$ or long term. ${ }^{15-17,19,20}$ The protocol used in our case followed steps already described in other studies, both about the choice of the donor and the surgical technique and graft implantation site. ABO compatibility was also performed to reduce the chance of graft rejection.

We could suggest a possible cause for non-functionality of the graft using short-term immunosuppression (ten days of corticosteroids) without HLA compatibility. However, it is not a hypothesis that can be affirmed since PTH levels have not increased until then, which may be due to structural factors and the blood supply of the graft.

\section{CONCLUSION}

This report demonstrated that parathyroid allotransplantation, as well as our immunosuppression protocol used, are safe procedures. Additionally, it showed that parathyroid allotransplantation might potentially provide a cure for permanent refractory hypoparathyroidism.

Since the fresh parathyroid tissue implanted in our patient did not show evidence of functionality, further studies are necessary to confirm the efficacy of this therapeutic strategy. 


\section{REFERENCES}

1. Clarke BL, Brown EM, Collins MT, Jüppner H, Lakatos P, Levine MA, et al. Epidemiology and diagnosis of hypoparathyroidism. J Clin Endocrinol Metab. 2016;101(6):2284-99.

2. Mannstadt M, Bilezikian JP, Thakker R V., Hannan FM, Clarke BL, Reijnmark L, et al. Hypoparathyroidism. Nat Rev Dis Prim. 2017;3.

3. Brandi ML, Bilezikian JP, Shoback D, Bouillon R, Clarke BL, Thakker R V., et al. Management of hypoparathyroidism: Summary statement and guidelines. J Clin Endocrinol Metab. 2016;101(6):2273-83.

4. Winer KK, Ko CW, Reynolds JC, Dowdy K, Keil M, Peterson $\mathrm{D}$, et al. Long-term treatment of hypoparathyroidism: A randomized controlled study comparing parathyroid hormone-(1-34) versus calcitriol and calcium. J Clin Endocrinol Metab. 2003;88(9):4214-20.

5. Rubin MR, Cusano NE, Fan WW, Delgado Y, Zhang C, Costa AG, et al. Therapy of hypoparathyroidism with $\mathrm{PTH}(1-84)$ : A prospective six year investigation of efficacy and safety. J Clin Endocrinol Metab. 2016;101(7):2742-50.

6. Clarke BL, Vokes TJ, Bilezikian JP, Shoback DM, Lagast H, Mannstadt M. Effects of parathyroid hormone $\operatorname{rhPTH}(1-84)$ on phosphate homeostasis and vitamin D metabolism in hypoparathyroidism: REPLACE phase 3 study. Endocrine [Internet]. 2017;55(1):273-82. Available from: http://dx.doi.org/10.1007/ s12020-016-1141-0

7. Gafni RI, Langman CB, Guthrie LC, Brillante BA, James R, Yovetich NA, et al. Hypocitraturia Is an Untoward Side Effect of Synthetic Human Parathyroid Hormone (hPTH) 1-34 Therapy in Hypoparathyroidism That May Increase Renal Morbidity. J Bone Miner Res. 2018;33(10):1741-7.

8. Gafni RI, Collins MT. Hypoparathyroidism. N Engl J Med. 2019;380(18):1738-47.

9. Nawrot I, Woźniewicz B, Tołłoczko T, Sawicki A, Górski A, Chudziński W, et al. Allotransplantation of cultured parathyroid progenitor cells without immunosuppression: Clinical results. Transplantation. 2007;83(6):734-40.

10. Cabané P, Gac P, Amat J, Pineda P, Rossi R, Caviedes R, et al. Allotransplant of Microencapsulated Parathyroid Tissue in Severe Postsurgical Hypoparathyroidism: A Case Report. Transplant Proc [Internet]. 2009;41(9):3879-83. Available from: http://dx.doi. org/10.1016/j.transproceed.2009.06.211

11. Yucesan E, Goncu B, Basoglu H, Ozten Kandas N, Ersoy YE, Akbas F, et al. Fresh tissue parathyroid allotransplantation with short-term immunosuppression: 1-year follow-up. Clin Transplant [Internet]. 2017 Nov;31(11):e13086. Available from: http://doi. wiley.com/10.1111/ctr.13086

12. Aysan E, Yucesan E, Idiz UO, Goncu B. Discharging a Patient Treated With Parathyroid Allotransplantation After Having Been Hospitalized for 3.5 Years With Permanent Hypoparathyroidism: A Case Report. Transplant Proc [Internet]. 2019;51(9):3186-8. Available from: https://doi.org/10.1016/j.transproceed.2019.03.036
13. Yucesan E, Goncu B, Ozdemir B, Idiz O, Ersoy YE, Aysan E. Importance of HLA typing, PRA and DSA tests for successful parathyroid allotransplantation. Immunobiology [Internet]. 2019;224(4):485-9. Available from: https://doi.org/10.1016/j. imbio.2019.05.007

14. Yucesan E, Basoglu H, Goncu B, Akbas F, Ersoy YE, Aysan E. Microencapsulated parathyroid allotransplantation in the omental tissue. Artif Organs. 2019;43(10):1022-7.

15. Torregrosa NM, Rodríguez JM, Llorente S, Balsalobre MD, Rios A, Jimeno L, et al. Definitive treatment for persistent hypoparathyroidism in a kidney transplant patient: Parathyroid allotransplantation. Thyroid. 2005;15(11):1299-302.

16. Chapelle T, Meuris K, Roeyen G, De Greef K, Van Beeumen G, Bosmans JL, et al. Simultaneous Kidney-Parathyroid Allotransplantation From a Single Donor After 20 Years of Tetany: A Case Report. Transplant Proc [Internet]. 2009;41(2):599-600. Available from: http://dx.doi.org/10.1016/j.transproceed.2008.12.026

17. Flechner SM, Berber E, Askar M, Stephany B, Agarwal A, Milas M. Allotransplantation of cryopreserved parathyroid tissue for severe hypocalcemia in a renal transplant recipient. Am J Transplant. 2010;10(9):2061-5.

18. Hermosillo-Sandoval JM, Leonher-Ruezga KL, Jiménez-Gómez JA, Fuentes-Orozco C, González-Ojeda A, Ramírez-González LR. Alotrasplante de paratiroides: seguimiento a 2 años. Cir Cir [Internet]. 2015 May;83(3):188-92. Available from: http://linkinghub.elsevier. com/retrieve/pii/S0009741115000602

19. Garcia-Roca R, Garcia-Aroz S, Tzvetanov IG, Giulianotti PC, Campara M, Oberholzer J, et al. Simultaneous Living Donor Kidney and Parathyroid Allotransplantation: First Case Report and Review of Literature. Transplantation. 2016;100(6):1318-21.

20. Agha A, Scherer MN, Moser C, Karrasch T, Girlich C, Eder F, et al. Living-donor parathyroid allotransplantation for therapy-refractory postsurgical persistent hypoparathyroidism in a nontransplant recipient - Three year results: A case report. BMC Surg [Internet]. 2016;16(1):16. Available from: http://dx.doi.org/10.1186/s12893-016-0165-y

21. Aysan E, Altug B, Ercan C, Toka C, Idiz UO, Muslumanoglu M. Parathyroid allotransplant with a new technique: A prospective clinical trial. Exp Clin Transplant. 2016;14(4):431-5.

22. Khryshchanovich V, Ghoussein Y. Allotransplantation of macroencapsulated parathyroid cells as a treatment of severe postsurgical hypoparathyroidism: Case report. Ann Saudi Med. 2016;36(2):143-7.

23. Hasse C, Klöck G, Schlosser A, Zimmermann U, Rothmund M. Parathyroid allotransplantation without immunosuppression. Lancet [Internet]. 1997 Nov;350(9087):1296-7. Available from: https:// linkinghub.elsevier.com/retrieve/pii/S0140673605624737

24. Journal A. Special Issue: KDIGO Clinical Practice Guideline for the Care of Kidney Transplant Recipients. Am J Transplant. 2009;9(Suppl 3):S1-155.

\section{How to cite:}

Gadelha DD, Alves W Filho, Brandão MA, Oliveira CM, d'Alva CB, Fernandes VO, et al. Living-donor fresh parathyroid tissue allotransplantation as treatment for permanent hypoparathyroidism: case report. Rev Med UFC. 2021;61(1):1-4. 